\title{
ANCIENT AFRICA AND THE TEACHING OF HISTORY
}

Raquel dos Santos Funari ${ }^{1}$

\begin{abstract}
The paper deals with the subject of ancient Africa in teaching of history in Brazil. It deals with the ways in which African Antiquity has been and can be portrayed in education, to propose a more complex, profound and inspiring picture. It turns to the antiquity of human presence in Africa, through learning situations. Egypt shines as part of African culture. It concludes by stressing the role of history classes for the recognition of African presence much before and beyond the modern period.
\end{abstract}

\section{Key-words}

Africa; Teaching of history; Ancient Egypt; ancient history.

\section{Resumo}

O artigo trata da África Antiga no ensino de história no Brasil. Trata, ainda, das maneiras como a África Antiga tem sido e pode ser retratada na educação, para propor um retrato mais complexo, profundo e inspirador. Volta-se, em seguida, para a presença humana na África, por meio de situações de aprendizagem. O Egito destaca-se como parte da cultura africana. Conclui-se por enfatizar o papel das aulas de História para reconhecer a presença africana muito antes e para além do período moderno.

\section{Palavras chave}

África; Ensino de História; Egito Antigo; História Antiga.

\footnotetext{
${ }^{1}$ PhD - State University of Campinas, Campinas, Brazil. E-mail: raquelsfunari@uol.com.br
} 


\section{Introduction: Africa beyond commonplace}

In Brazil, whenever the topic of Africa is brought up, there is an almost inevitable tendency to deal with Modern Sub-Saharan Africa, after the fifteenth century. In fact, Brazilian schoolchildren are taught from an early age - in class and through textbooks - about the Portuguese maritime expansion, first on the African continent, then in America. Hence, and in a perfectly logical way, the relationships between the Portuguese colony on our side of the Atlantic and those on the other side turn into the main narrative about our history. African slaves contributed to Brazilian culture almost from the start, with most of the country's population being African or of African descent, at least until the abolition of slavery in 1888. Later history cannot be dissociated from Afro-Brazilian presence either, to the point that samba became a synonym of our country, both in its popular and more erudite versions, such as Bossa Nova. There is simply no Brazil without its Sub-Saharan African matrix.

But relevant as those times may have been, there is much more to African history than just that. Our links to Africa are far older and more profound, although they are not always recognized or indeed associated to that continent. In this article I aim to deal with the teaching of History, a fundamental yet often underestimated field of action. The vast majority of people become aware of the past, of history as a narrative, through primary and secondary schooling. History's practitioners, professors and researchers, constitute less than $1 \%$ of the population. As a teacher, supervisor and professional in the field of history this has always struck me as an essential aspect to be taken into consideration. Whatever children learn about the past, at school, is what will make future citizens.

Hence my interest in the topic of Ancient Africa at schools. Modern Africa, marked by slavery, colonization and poverty, could result in the reinforcement of stereotypes, whose pernicious effects in our society could be profoundly negative. Both the insufficient economic development and the century-deep persistence of social inequalities have often been unjustly associated to African heritage, whether through enslavement or the notion of work devaluation that is associated to it.

On the other hand, none of this can withstand the filter of the slightest critical analysis aimed at accounting for realities beyond mere appearances. Modernity has gone far beyond, and the reasons for the persistence of inequality, racism and discrimination are many, but overall related to a far too narrow image of the African continent. In this article I will deal with the ways in which African Antiquity has been and can be portrayed in education, to propose a more complex, profound and inspiring picture. 


\section{The Antiquity of African humanity}

To begin with, we should not lose sight of human antiquity, which was, for millions of years, restricted to the African continent. Africa was the home of countless species of primates, our direct or indirect ancestors, and therefore constitutes humanity's original cradle. Even if we were to restrict ourselves to our own species, homo sapiens, Africa was the original land of all humans. Until 2017, genetic data and the morphology of skeletons indicated an antiquity of between 50 and 150 million years, in Morocco. We should not be surprised at this, given the periods of continuity in the vegetable and animal occupation of Sahara which was, intermittently and for long millennia, a savannah.

How does all of this feature in Brazilian schools? The simplest and most immediate answer would, for a number of reasons, be very little. To begin with, the study of the most distant roots of human origins has been granted very little space in textbooks and even less in the classroom. Schoolbooks do not even deal with that longer and deeper past and this is also reflected in History teachers' very training. This is partly due to the fact that primitive humans are placed in the realm of biological species, which are, within reasonable limits, largely the topic of biology lessons. In any case, $99 \%$ of human history, until the invention of writing some five thousand years ago are either quickly overviewed or ignored. To the extent that teachers have very poor training in the area, it would only seem natural that they should leave it aside in the classroom. The result is to ignore that all humans are Africans or of African descent.

My own experience both as author and as a teacher shows the potential of such an approach to the depth of African history with young children. As an author, the inclusion of such topics in manuals has been very well-received. I have been had the chance to confirm such positive appraisals whenever the discussion of such questions is included. The very fact that training tends to be poor in such areas evidently makes dealing with such questions far from easy. However, there is much curiosity and interest among professionals and students alike. Indeed, it seems to be a liberating discovery: the antiquity of African humanity restates notions about shared human values beyond historical and cultural particularities. In other words, we are all human, we all share the same common ancestors and we are all responsible for the destiny of each one of us, of all humanity.

This reflects the deep spiritual values of both secular and religious sensibilities: to love others as much as oneself; that everyone is equal and everyone is different, but we all share the same prerogatives. According to such scholars as François Hartog there are three approaches: past-based approaches, enlightened approaches and post-modern approaches. Regardless of which we 
prefer, they all share respect for the other in different ways. In this particular case, awareness of our common African descent dissolves any remainder of justification for discrimination. Time and time again I have experienced how this topic appeals to young children, who find in the common humanity of all human beings a way of overcoming divisions among themselves.

Then comes the great topic of Africa during antiquity, from the invention of writing, at around 3,200 B.C. History textbooks dedicate a substantial part of their contents to the Ancient World, and Brazilian State and Federal curricula deal with this period (3,200 B.C.-476 A.C.) and cultures in detail. The Common Curricular National Base, (CCNB) published in 2017 featured the following topics:

CCNB $6^{\text {th }}$ year, p. 370

- The invention of the Classical World in contrast to other societies.

- Ancient Peoples of Africa (Egyptians) the Middle East (Mesopotamia) and the Americas.

- Notions of citizenship and politics in Greece and Rome.

- Dominions and expansion of Greek and Roman cultures

- Meanings of the concept of "empire" and rationalities of conquest, conflict and negotiation of such forms of political organization

- Different forms of political organization in Africa: kingdoms, empire, city-states and lineage or hamlet societies

- The Mediterranean as a space of interaction among societies in Europe, Africa and the Middle East

\section{Page 371}

- Lords and servants in the ancient and medieval worlds

- Slavery and free work across different times and places (Ancient Rome, Medieval Europe and Africa)

\section{Page 372}

- Identifying aspects and forms of recording ancient societies in Africa, the East and the Americas, distinguishing certain meanings present in those societies' material culture and oral traditions.

In the case of the State of São Paulo (http://www.educacao.sp.gov.br/saopaulo-faz-escola) the same is also clear:

- Civilizations of the Near East 
- Ancient Egypt and Mesopotamia

- Africa the "cradle of Humanity"

- Recognizing Africa as the place of the emergence of humanity based on archaeological data and vestiges.

The teaching materials used in the state of São Paulo can be assessed through this fragment about our common African heritage

Learning situation 3: Africa, cradle of humanity

Activity: Archaeological vestiges found in Africa,

The aim of the activity is to analyze the importance of the African continent for archaeological research about humanity's different development phases. Scholars from different areas have taken part in different research programs in search for vestiges, artefacts, ceramic vases, and hearth remains enabling a full assessment of the African continent's importance for the history of humanity.

The third learning proposal's aim is to use a panel of different artefacts made mainly with a sketch of the African map, to show the vestiges of our common history. We know that our most ancient ancestors emerged from the African continent and lived there throughout most of history. The species that gave rise to modern human beings lived in Africa seven million years ago. The first human beings to exit Africa did so only 100,000 years ago. Therefore, over $95 \%$ of our history took place on African soil. This alone makes it important that we should study Africa, the cradle of humanity.

It is also worth quoting the significant passage below:

Africa is therefore, in every possible way, the cradle of humanity. The oldest hominoids were located in Eastern Africa (Ethiopia, Kenya, South Africa).

Such is Africa's first importance. Immediately after that, and closer to us in time, it is important for us to be aware of Africa's rich history over the last 10,000 years, a period which corresponds to the time we live (Holocene). Africa hosts a wide and diverse set of languages, but scholars have grouped languages and dialects into four major groups.

The two most recent groups from outside of Africa are the Germanic languages of South Africa and the Asian languages spoken in Madagascar. On the continent itself there are four major groups, from North to South: Afro-Asian, Nile-Saharan, Niger-Kordofanian and Khoisan. Afro-Asian 
languages occupy the entire Mediterranean part, but also part of the Indian Ocean. These groups seem to have originated at some point in the continent's Northeast thousands of years ago, having originated such languages as Ancient Egyptian, but also languages we associate today to Asia, such as Hebrew and Arabic. Such Middle Eastern peoples also the umbilical cord that also links them to Africa.

Egypt is in Africa, the languages used there in the past and present are African: what is meant by the African character of Egypt? What this perspective aims to highlight are the African contributions, defined in contrast to other important ancient civilizations, such as those in Mesopotamia (the Sumerians, Babylonian, Assyrians) as well as the Hebrew, Greek, and Roman civilizations, to quote the most well-known. It is of course a difficult and risky exercise, as we are all human beings and the civilizations quoted above interacted amongst themselves and there is no way of separating purely African elements from Asian or European ones. The intention is not therefore to isolate African elements from all others, but to show how several African characteristics are present in the Egyptian civilization and, for the same reason, were so welcomed elsewhere in the world.

Perhaps the strongest African cultural element in the Egyptian civilization and with the greatest repercussion is a specific aspect of religiosity: the belief in souls, in life after death through resurrection. Already at the start of the Pharaonic period, when written hieroglyphs are available (towards the end of the fourth millennium B.C.), the Egyptians believed that people had several forms of spirit and body: the khat (body), jb (heart), rn (name), ka (life spirit), shut (shadow), ba (the immortal soul). Such unique spiritual riches linked to life is well rooted in African traditions, and are also known, in other forms, in the spirituality of Sub-Saharan African peoples. It is no coincidence that peoples elsewhere in the world at different times were inspired by Egyptian conceptions about the soul, from the most ancient Greeks to the modern - and in Brazil, many -followers of modern spiritism.

Still within the spiritual and religious realm the topic of resurrection, which is present in the myth of Osiris, also deserves attention. Osiris was assassinated by his brother Seth, who coveted his throne. Isis managed to bring him back to life through an enchantment she had learnt from her father, which allowed Osiris to make her pregnant before his return from the kingdom of the dead, giving birth to the god Horus. This conception of Renaissance was so strong that, during the Roman Empire (31 B.C-410 A.C.) the cult of Isis became one of the most popular. The oldest known beliefs in resurrection come from Egypt and, while they have also emerged in other parts of the planet, and independently, Egyp- 
tian notions were particularly relevant for the later expansion and success of Christianity, which spread over Egypt as early as the first Century A.C., and later - from the fifteenth century onwards, across Sub-Saharan Africa, building on the combination of those expectations about life after death.

Beyond spirituality, other aspects of Egyptian civilization are highly uncommon among other peoples, and are also connected to the African continent- namely the role of women. While Eastern and Greek civilization confined women to a very limited social space, Egyptian women enjoyed, from the earliest historical periods at the end of the Fourth millennium, prominent social positions. Egyptian women's bodies were more freely represented, and they could not only exhibit their beauty, but female ornaments had value attached to them from very early on, many of these female representations having reached us thanks to archaeological research. Women were valued for their fertility, but also for their beauty and intellectual and political ability. Some queens became very famous, such as Hatshepsut (1508-1458 B.C.), Nefertiti (1370-1330) and Cleopatra (69-30 A.C.). Hatshepsut was a female pharaoh, Nefertiti was the queen and counsellor of pharaoh Akenaton, who introduced monotheism, and is today recognized as one of the most beautiful women of all times, based on the statue of her preserved at the Berlin museum. While coming from a Macedonian family, Cleopatra was the queen of Egypt in the local tradition and was considered one of the most powerful, intelligent and charming women of all time. Also in this respect, it cannot be forgotten that many traditional African societies grant women an intense social life that stands in stark contrast to the segregation which is common in other civilizations, in many other aspects, even as spiritual leaders (from a Brazilian perspective, how not to think of the female spiritual and religious leaders, Mãe de Santo).

In the curriculum of the State of São Paulo, one passage among others shows the umbilical links from Ancient Egypt in the African continent, and the East:

Questions proposed for the final evaluation.

Question 1: (open)

What is the origin of the term "Fertile Crescent?"

\section{ANSWER}

The term "Fertile Crescent" was created by the North American archaeologist James Henri Breasted, at the start of the Twentieth Century. This great scholar of the Middle East proposed this name to designate the arch which, in its crescent moon shape, between the Persian Gulf, Mesopotamia, Syria and Lebanon, Palestine and Egypt. This area is located between the Asian 
and African continents, close to Europe, which favored uncommon biodiversity. From the end of the Pleistocene (9.500 B.C.), this area witnessed the development of agriculture, ceramics, cities and great civilization. The term "Fertile Crescent" refers to the fertility of the soil, when irrigated by rivers, for agriculture, but also for cultural fertility, which allowed the emergence of so many civilizations. The image of the crescent moon was inspired by the image projected by the moon (between the Persian Gulf and Upper Egypt, in the shape of an arch, which goes across Lebanon and Palestine), but also in the crescent moon which is the symbol of Islam, the dominant religion in the region today.

Abilities and competences: in answering this question, the student can demonstrate that they are proficient in the use of the Portuguese language and that they can draw on their knowledge of texts to identify the meaning of the "Fertile Crescent"; they can also show their ability to relate information to construct a consistent argument.

\section{Conclusion}

The teaching of history has deserved increasing attention, particularly due to the fact that it is charge of educating future citizens. There is consensus among analysts that educational training is a necessary condition for countries to both develop and to make such development benefit the majority while contributing to the decrease of social differences. This road has been travelled by such countries as South Korea, Portugal, Chile or Botswana, in a diminishing order of the correlation between life standards and education. What matters most is that general investment in education brings about an improvement of life conditions, even in the case of such poor countries as India.

Knowledge of history has a fundamental role as part of this training, as it provides a general context which, along with the capacity for expression which it cannot be separated from, sustains any adult's critical thinking. In the specific case of our country, among the leading nations in social differences around the world, education has a strategic role. The African continent in its antiquity features prominently in both the Common National Curricular Base and the State of São Paulo curriculum discussed in this article, in two major ways: First, Africa as humanity's common cradle and secondly, the Egyptian civilization in the context of the African continent. The teaching of history, the making of future citizens, can thus contribute to instigating a wider critical and humanistic critique. In this respect, ancient history plays a major role. 


\section{Bibliography}

ALBUQUERUQE, W.R.; FRAGA FILHO, W. Uma História do Negro no Brasil. Brasília, Fundação Cultural Palmares, 2006.

BAKOS, M.; FUNARI, R. S. . História da tradição clássica no Brasil dos séculos XIX e XX. Egito antigo no Brasil: egiptologia e egiptomania. In: André Leonardo Chevitarese; Gabriele Cornelli; Maria Aparecida de Oliveira Silva. (Org.). Tradição Clássica e o Brasil. 1 ed. Brasília: Fortium/Archai, 2008, v. 1, p. 143152.

BAKOS, M.M. Egiptomania, o Egito no Brasil. São Paulo, Paris, 2004.

BARBUJANI, Guido. A invenção das raças. São Paulo: Contexto, 2008.

BERNAL, M. A imagem da Grécia Antiga como uma ferramenta para o colonialismo e para a hegemonia europeia. In Pedro Paulo A. Funari (Org.). Repensando o Mundo Antigo. Campinas: IFCH/UNICAMP, 2005.

BLYDEN, E.W. A invenção de África: gnose, filosofia e a ordem do conhecimento. Luanda/Mangualde (Portugal): Edições Mulemba/Edições Pedago, 2013, p. 129-170.

CARDOSO, C.F.S. O Egito Antigo. São Paulo, Brasiliense, 1982.

COSTA E SILVA, A. A Enxada e a lança. A África antes dos portugueses. Rio de Janeiro, Nova Fronteira, 1992.

A manilha e o Libambo. A África e a escravidão, 1500 A 1700. Rio de Janeiro, Nova Fronteira, 2002.

. Um Rio Chamado Atlântico. A África no Brasil e o Brasil na África. Rio de Janeiro, Nova Fronteira, 2003.

FEITOSA, L. M. G. C.; FUNARI, P. P. A. (Org.); ZANLOCHI, T. S. (Org.) . As veias negras do Brasil: conexões brasileiras com a África. 1. ed. Bauru: EDUSC, 2012. v. 1.

FONSECA, Maria Nazareth Soares. (org.) Brasil afro-brasileiro. Belo Horizonte: Autêntica, 2000.

FUNARI, R.S. Egypt and Brazil. In: New perspectives on the ancient world. Oxford, Archaeopress, 2008. p. 73-76.

FUNARI, R.S. Imagens do Egito Antigo. São Paulo, Annablume/Unicamp, 2006. 
FUNARI, R.S. O Egito dos faraós e sacerdotes. São Paulo, Atual, 2001.

FUNARI, R.S. O interesse pelo Egito faraônico: uma aproximação inicial. In: História Antiga, contribuições brasileiras. São Paulo, Annablume/Fapesp, 2008. p. 93-100.

GORENDER, Jacob. O escravismo colonial. 6 ed. São Paulo: Ática, 2001.

GRALHA, J.C.M. Egípcios. In: As religiões que o mundo esqueceu. São Paulo, Contexto, 2009. p. 11-27.

HEYWOOD, Linda M. Diáspora negra no Brasil. São Paulo: Contexto, 2008.

JOHNSON, P. História Ilustrado do Egito Antigo. Rio de Janeiro, Ediouro, 2002.

KI-ZERBO, Joseph (Coord.). História geral da África. São Paulo: Ática/Unesco, 1982.

KI-ZERBO, Joseph (Ed.). História geral da África: I: Metodologia e pré-história da África. Trad. MEC/Centro de Estudos Afro-Brasileiros da UFSC. São Paulo/Brasília: Cortez/UNESCO, 2011.

MAESTRI, Mário. A Servidão Negra. Porto Alegre: Mercado Aberto, 1988.

MAESTRI, Mario. História da África Negra Pré-Colonial. Porto Alegre: Mercado Aberto, 1988.

MATTOS, Regiane de. História e cultura afro-brasileira. São Paulo: Contexto, 2008.

MESKELL, L. Intimate archaeologies. The case of Kha and Merit. World Archaeology: Intimate Relations,29/3. p. 363-379.

MESKELL, L. Size matters: sex, gender and status in Egyptian iconography. In J. Hope et al. (eds) Redefining Archaeology: Feminist Perspectives. Canberra, ANU Press: Canberra, 1998. p. 175-181.

MESKELL, L.; JOYCE, R. Embodied lives. Figuring ancient Maya and Egyptian experience. Londres, Routldege, 2003.

MUNANGA, Kabenguele. Rediscutindo a Mestiçagem no Brasil. Identidade Nacional versus identidade negra. Petrópolis, Rio de Janeiro: Vozes, 1999.

NASCIMENTO, Abdias. O Quilombismo. Documentos de uma militância pan-africanista. Brasília: Fundação Cultural Palmares/ Rio de Janeiro: OR Editor Produtor Editor, 2002. 
PINSKY, J. As primeiras civilizações. São Paulo, Contexto, 2008.

Reis, J.J. GOMES, Flávio dos. Liberdade por um Fio. São Paulo: Companhia das Letras, 1996

SCHWARCZ. Lilia Moritz. O espetáculo das raças. cientistas, instituições e questão racial no Brasil no Brasil do século XIX. São Paulo: Companhia das Letras, 1993.

SHAW, I. Ancient Egypt. Oxford, Oxford University Press, 2004.

SILIOTTI, A. Primeiros descobridores. A descoberta do Egito. Barcelona, Folio, 2007.

SILIOTTI, A. Viajantes e exploradores. A descoberta do Egito. Barcelona, Folio, 2007.

STEER, D.A. Egiptologia. São Paulo, Briquebooks, 2009.

THORTON, John. A África e os africanos na formação do Mundo Atlântico, 14001800. Rio de Janeiro, Campus, 2003.

VERCOUTER, J. Em busca do Egito esquecido. São Paulo, Objetiva, 2002.

VIDAL-MANZANARES, C. Diccionario histórico del antiguo Egipto. Madri, Alianza, 1993. 